Modelling daily streamflow at ungauged catchments: what information is necessary?

Patil, S.D.; Stieglitz, M.

\title{
Hydrological Processes
}

DOI:

10.1002/hyp.9660

Published: 28/12/2012

Peer reviewed version

Cyswllt i'r cyhoeddiad / Link to publication

Dyfyniad o'r fersiwn a gyhoeddwyd / Citation for published version (APA):

Patil, S. D., \& Stieglitz, M. (2012). Modelling daily streamflow at ungauged catchments: what information is necessary? Hydrological Processes, 28(3), 1159-1169.

https://doi.org/10.1002/hyp.9660

\section{Hawliau Cyffredinol / General rights}

Copyright and moral rights for the publications made accessible in the public portal are retained by the authors and/or other copyright owners and it is a condition of accessing publications that users recognise and abide by the legal requirements associated with these rights. study or research.

download and print one copy of any publication from the public portal for the purpose of private

- You may not further distribute the material or use it for any profit-making activity or commercial gain

- You may freely distribute the URL identifying the publication in the public portal ?

Take down policy

This is the peer reviewed version of the following article: Patil, S.D. and Stieglitz, M. (2014), Modelling daily streamflow at ungauged catchments: what information is necessary? Hydrol. Process., 28: 1159-1169 which has been published in final form at doi: $10.1002 / h y p .9660$. This article may be used for non-commercial purposes in accordance with Wiley Terms and Conditions for Self-Archiving. Copyright (C) 2012 John Wiley \& Sons, Ltd

Take down policy

If you believe that this document breaches copyright please contact us providing details, and we will remove access to the work immediately and investigate your claim. 
NOTICE: This is the author's version of a work that was peer reviewed and accepted for publication in Hydrological Processes journal. Changes resulting from the publishing process, such as editing, corrections, structural formatting, and other quality control mechanisms may not be reflected in this document. A definitive version was subsequently published in HYDROLOGICAL PROCESSES, VOL 28, DOI\# http://dx.doi.org/10.1002/hyp.9660.

\title{
Modeling daily streamflow at ungauged catchments: What information is necessary?
}

\author{
Sopan Patil ${ }^{1 *}$ and Marc Stieglitz ${ }^{1,2}$ \\ ${ }^{1}$ School of Civil and Environmental Engineering, \\ Georgia Institute of Technology, Atlanta, GA 30332 \\ ${ }^{2}$ School of Earth and Atmospheric Sciences, \\ Georgia Institute of Technology, Atlanta, GA 30332 \\ * Current affiliation: National Health and Environmental Effects Research Laboratory, \\ U.S. Environmental Protection Agency, Corvallis, OR 97333
}

Corresponding author: sopan.patil@gmail.com

Submission to:

Hydrological Processes 


\section{Abstract}

2 Rainfall-runoff modeling at ungauged catchments often involves the transfer of calibrated model

3 parameters from "donor" gauged catchments. However, in any rainfall-runoff model, some

4 parameters tend to be more sensitive to the objective function, whereas others are insensitive

5 over their entire feasible range. In this paper, we analyze the effect of selectively transferring

6 sensitive vs. insensitive parameters on streamflow predictability at ungauged catchments. We

7 develop a simple daily time-step rainfall-runoff model (EXP-HYDRO) and calibrate it at 756

8 catchments within the continental United States. Nash Sutcliffe efficiency of $\sqrt{Q}$ (NS) is used

9 as the objective function. The model simulates satisfactorily at 323 catchments (NS > 0.6), most

10 of which are located in the eastern part of US, along the Rocky Mountain Range, and near the

11 western Pacific coast. Of the six calibration parameters, only three parameters are found to be

12 sensitive to NS. Two of these parameters control the hydrograph recession behavior of a

13 catchment and the third parameter controls the snowmelt rate. We find that when only sensitive

14 parameters are transferred, model performance at ungauged catchments is almost on par with that

15 of transferring all six parameters. Conversely, transfer of only insensitive parameters results in

16 significant deterioration of model performance. Results suggest that streamflow predictability at

17 ungauged catchments using rainfall-runoff models is largely dependent on the transfer of a small

18 subset of parameters. We recommend that, in any modeling framework, such parameters should

19 be identified and further characterized to better understand the information controlling

20 streamflow predictability at ungauged catchments. 


\section{Introduction}

Rainfall-runoff models are the essential tools for prediction of catchment streamflow and are applied for numerous tasks in hydrology. These tasks include: short-term streamflow

27 forecasting [Zealand et al., 1999; Shukla and Lettenmaier, 2011], flood frequency estimation [Merz and Blöschl, 2005; Moretti and Montanari, 2008], water quality assessment [Krysanova et al., 1998; Servais et al., 2007], low flow predictions [Smakhtin, 2001; Rees et al., 2004; Staudinger et al., 2011], study of the ecosystem services linked to catchment hydrologic functioning [Poff et al., 2010; Abdelnour et al., 2011; Notter et al., 2012], and assessment of 32 climate change impacts on water availability [Hamlet and Lettenmaier, 1999; Christensen et al., 2004; Xu et al., 2011]. A variety of rainfall-runoff models have been developed over the years and successfully implemented at catchments across the world (see reviews by Singh [1995], Beven [2001], Singh and Woolhiser [2002], and Singh and Frevert [2006]). However, regardless of the model used, an important prerequisite for streamflow prediction involves calibration of model parameters using observed streamflow data [Beven, 2001]. Unfortunately, majority of the catchments throughout the world are ungauged (i.e., they lack streamflow observations). 39 Therefore, a challenge for hydrologists is to develop tools and strategies for predicting streamflow at these ungauged catchments [Sivapalan et al., 2003; Wagener and Montanari, $2011]$. following procedure: (1) calibration of model parameters at gauged catchments using the 44 observed streamflow data, and (2) transfer of the calibrated parameters from gauged to ungauged catchments that are perceived to be hydrologically similar [Oudin et al., 2010]. Here, we define 
47 highly correlated to each other [Archfield and Vogel, 2010; Patil and Stieglitz, 2012]. Since

48 streamflow data is not available at ungauged catchments, indirect characterization of hydrologic

49 similarity becomes essential [Blöschl, 2006]. Two similarity approaches, viz., spatial proximity

50 and physical similarity, have been shown to work successfully in many regions. In the spatial

51 proximity approach, a gauged catchment that is located closest to the ungauged catchment is

52 assumed to be hydrologically similar [Mosley, 1981; Vandewiele et al., 1991; Vandewiele and

53 Elias, 1995; Merz and Blöschl, 2004]; whereas in the physical similarity approach, a gauged

54 catchment that is most similar to the ungauged catchment in physical attribute domain is

55 assumed to be hydrologically similar [Burn and Boorman, 1993; Parajka et al., 2005; Oudin et

56 al., 2010]. Studies that have compared these two approaches show that none has a clear

57 advantage over the other for predicting streamflow at an ungauged catchment. For example,

58 Parajka et al. [2005] used HBV model at 320 catchments in Austria and found that the physical

59 similarity approach slightly outperformed the spatial proximity approach for catchments in

60 Austria. On the other hand, Oudin et al. [2008] and Zhang and Chiew [2009] found that the

61 spatial proximity approach performed marginally better than the physical similarity approach for

62 estimating model parameters at ungauged catchments in France (913 catchments) and Australia

63 (210 catchments), respectively.

Irrespective of the approach used, similarity-based procedures for parameter estimation

65 typically involve transfer of all calibrated parameters from gauged to ungauged catchments

66 [Merz and Blöschl, 2004; McIntyre et al., 2005; Oudin et al., 2008]. However, studies have

67 shown that the identifiability of an optimal parameter value is not similar for all model

68 parameters [Beven, 1989; Beven and Binley, 1992; Doherty and Hunt, 2009]. Specifically, some

69 model parameters tend to be more sensitive to the objective function (i.e., their optimal values 
can be better constrained), whereas others can be insensitive over their entire feasible range. As

71 a result, it is not entirely clear if all model parameters are equally important for transfer to

72 ungauged catchments or if some parameters provide more hydrologically meaningful

73 information than others, and should be preferentially transferred.

74 In this study, we hypothesize that there is some core information, contained within a

75 subset of all the calibrated model parameters, whose transfer from gauged to ungauged 76 catchments is the most critical factor for successful streamflow predictions. To test this

77 hypothesis, we develop a simple daily time-step rainfall-runoff model (EXP-HYDRO) and

78 implement it at 756 catchments across the continental United States. The EXP-HYDRO model

79 contains six free calibration parameters. We first determine which model parameters are to be

80 considered as important (or not important) based on their sensitivity to our objective function.

81 We then compare the model performance at ungauged catchments by selectively transferring the

82 different types of parameters. Both spatial proximity and physical similarity approaches are used 83 to identify the donor gauged catchments for parameter transfer.

\section{2. Data and Model}

\section{$86 \quad 2.1 \quad$ Data}

87 We use daily streamflow data of 756 catchments from U. S. Geological Survey's Hydro-

88 Climate Data Network (HCDN) (Slack et al., [1993]; see Figure 1). The HCDN database 89 consists of data of 1659 catchments located within the United States that are not severely 90 affected by human activity and its record spans from 1874 to 1988 . A majority of the catchments

91 have consistent and continuous records from water year 1970 onwards. We consider only those 92 catchments that have a continuous daily streamflow record from water year 1970 to 1988 (i.e., 
1st October, 1969 to 30th September, 1988), which reduces the number of acceptable catchments

94 to 756 . The drainage area of the catchments ranges from $23 \mathrm{~km}^{2}$ to $5100 \mathrm{~km}^{2}$, whereas the 95 average annual precipitation at the catchments ranges from $320 \mathrm{~mm}$ to $3300 \mathrm{~mm}$.

96 Historical daily air temperature and precipitation data are obtained from the dataset 97 developed by Maurer et al. [2002]. This data is gridded at $1 / 8$ degree (about $14 \mathrm{~km}$ ) spatial

98 resolution and covers the entire continental United States. For each catchment, we also obtain 99 data for five physio-climatic attributes from the dataset developed by Vogel and 100 Sankarasubramanian [2005]. These attributes are: mean elevation above sea level, channel 101 slope, soil permeability, solar radiation, percentage precipitation as snow. Aridity index (PET/P) 102 is also calculated for each catchment from the available hydro-climatic data. Table 1 103 summarizes the physio-climatic attributes of all 756 catchments.

\section{$104 \quad 2.2 \quad$ Rainfall-runoff Model}

We have developed a simple spatially lumped rainfall-runoff model called EXP-HYDRO

106 (EXPonential bucket HYDROlogic model). This model operates at a daily time-step and 107 conceptualizes the catchment as a bucket store (Figure 2). The water balance equation of the 108 catchment bucket is as follows:

$$
\frac{d S}{d t}=P_{r}+M-E T-Q_{\text {bucket }}-Q_{\text {spill }}
$$

110 where, $S$ is the water stored in catchment bucket (unit: $\mathrm{mm}$ ), $P_{r}$ is the precipitation that falls as

111 liquid rainfall (unit: $\mathrm{mm} / \mathrm{day}$ ), $M$ is the snowmelt that occurs from the snow accumulation store 112 (unit: $\mathrm{mm} / \mathrm{day}$ ). The snowmelt is modeled using a simple thermal degree-day model whose 113 details are provided in Appendix A. ET is the evapotranspiration (unit: $\mathrm{mm} /$ day), $Q_{\text {bucket }}$ is the 114 runoff generated based on the available stored water in the bucket (unit: $\mathrm{mm} /$ day). $Q_{\text {spill }}$ is the 
115 capacity excess runoff (unit: $\mathrm{mm} /$ day) that occurs only when excess precipitation and/or 116 snowmelt is available to infiltrate into the catchment bucket, but the storage $S$ has reached full 117 capacity $S_{\max }$. The daily streamflow at catchment outlet is the sum of $Q_{b u c k e t}$ and $Q_{\text {spill }}$.

118 Evapotranspiration is calculated as a fraction of the potential evapotranspiration (PET), 119 and depends on the amount of actual stored water relative to the bucket storage capacity:

$$
E T=P E T \cdot\left(S / S_{\max }\right)
$$

121 PET (unit: $\mathrm{mm}$ /day) is obtained from daily air temperature using Hamon's formulation [Hamon, 122 1963]:

$$
P E T=29.8 \cdot D \cdot \frac{e_{s a t}\left(T_{a}\right)}{T_{a}+273.2}
$$

124 where, $D$ is the day length (unit: hours), which depends on the Julian date of the year and the 125 latitude of catchment location. D is calculated using the formula suggested by Dingman [2002] 126 (Appendix $\mathrm{E}$ in that book). $e_{\text {sat }}$ is the saturation vapor pressure (unit: $\mathrm{kPa}$ ), calculated as:

$$
e_{s a t}\left(T_{a}\right)=0.611 \cdot \exp \left(\frac{17.3 \cdot T_{a}}{T_{a}+237.3}\right)
$$

128 The amount of runoff generated from the catchment bucket depends on the amount of water 129 stored in it and is calculated using a TOPMODEL [Beven and Kirkby, 1979] type equation:

$$
Q_{\text {bucket }}=Q_{\max } \cdot \exp \left(-f \cdot\left(S_{\max }-S\right)\right)
$$

131 where, $Q_{\max }$ is the maximum runoff produced by the catchment bucket (unit: $\mathrm{mm} /$ day) when its 132 storage reaches the maximum capacity, and $f$ is the parameter controlling the storage-dependent 133 decline in runoff (unit: $\mathrm{mm}^{-1}$ ).

\section{Methods}



parameters at the 756 catchments. Then we describe the method used for identifying and 138 classifying the sensitive and insensitive model parameters. This is followed by a brief 139 description of the parameter transfer schemes used for estimating model parameters at ungauged 140 catchments.

\subsection{Model Calibration}

The EXP-HYDRO model contains six free calibration parameters $\left(f, Q_{\max }, S_{\max }, D_{f}, T_{\min }\right.$, and $T_{\max }$ ), of which, $D_{f}, T_{\min }$, and $T_{\max }$ are the parameters from snow model (see Appendix A).

144 For each catchment, we calibrate the above six parameters with 50,000 Monte Carlo simulations. 145 Table 2 shows the parameter ranges used for random sampling of these six parameters. First 146 year from the chosen time-period (water year 1970) is used for model spin-up, and the daily 147 streamflow data from remaining 18 years is used for parameter optimization. Nash Sutcliffe 148 efficiency [Nash and Sutcliffe, 1970] of square root values of daily streamflow is used as the 149 objective function:

$$
N S=1-\frac{\sum_{i=1}^{n}\left(\sqrt{Q_{o b s, i}}-\sqrt{Q_{p r e d, i}}\right)^{2}}{\sum_{i=1}^{n}\left(\sqrt{Q_{o b s, i}}-\sqrt{\bar{Q}_{o b s}}\right)^{2}}
$$

151 where, $Q_{\text {pred,i }}$ and $Q_{o b s, i}$ are the predicted and the observed streamflow values on the $i^{\text {th }}$ day

152 respectively, $\bar{Q}_{o b s}$ is the mean of all the observed streamflow values and $n$ is the total number of 153 days in the record. The commonly used variants of Nash-Sutcliffe efficiency formula are: 154 untransformed $(Q)$, square root transformed $(\sqrt{Q})$, and $\log$ transformed $(\log Q)$ [Oudin et al., 155 2006]. As an objective function, NS $(Q)$ tends to over-emphasize the matching of high flow 156 values (at the expense of low flows), whereas NS $(\log Q)$ tends to do the opposite. NS $(\sqrt{Q})$, 
157 however, balances out these two extremes and focuses on matching the overall hydrograph,

158 albeit at the expense of very high and very low flows. Since our objective in this study is to

159 match the overall hydrologic dynamics of a catchment over a long time period, we use NS ( $\sqrt{Q})$

160 as the objective function (Equation 6, and henceforth referred to simply as NS). Comparison of

161 different objective functions is beyond the scope of this study.

162

163

164

165

166

167

168

169

170

171

172

173

174

175

176

177

178

179

\subsection{Model parameter sensitivity}

To characterize the sensitivity of EXP-HYDRO model parameters, we implement a simple procedure that tests the improvement in model performance when a given parameter is assigned its calibrated value instead of a randomly sampled value. We begin with a baseline scenario where the values of all six parameters are randomly sampled within their feasible ranges (see Table 2). This baseline scenario is illustrated as Run 1 in Figure 3, where the solid gray bar shows the median NS of all 756 catchments and the error bars show the $25^{\text {th }}$ and $75^{\text {th }}$ percentile values of median NS (obtained through 1000 iterative model runs). We next fix each model parameter individually to its calibrated value (while still keeping the other five parameters random) and measure the increase in model performance from the baseline scenario. The maximum increase in median NS is obtained when $f$ is fixed to its calibrated value (Run 2 in Figure 3), which indicates that $f$ is the most sensitive parameter in the EXP-HYDRO model. For Run 3, we keep $f$ fixed and repeat the procedure from Run 2 by individually fixing each of the remaining five parameters to calibrated values. The largest increase in median NS during Run 3 is obtained when both $f$ and $S_{\max }$ are fixed (see Figure 3). This suggests that $S_{\max }$ is the second most sensitive parameter in the EXP-HYDRO model. The next largest increase in median NS is obtained when $f, S_{\max }$, and $D_{f}$ are fixed to their calibrated values (Run 4 in Figure 3). To identify the fourth most sensitive parameter, we next add the calibrated values of $Q_{\max }, T_{\min }$, and $T_{\max }$ 
180 individually to the list of fixed parameters (Runs 5, 6, and 7, respectively). However, we 181 observe that the increase in median NS is much smaller, and similar, when either of these 182 parameters is fixed to the calibrated values (Figure 3). This suggests that these three parameters 183 are equally sensitive (or insensitive) to the objective function. Therefore, we classify parameters $184 f, S_{\max }$, and $D_{f}$ as sensitive parameters, and $Q_{\max }, T_{\min }$, and $T_{\max }$ as insensitive parameters.

The above mentioned classification of parameters is consistent with visual observation of the dotty plots (widely used in GLUE methodology [Beven and Binley, 1992]) from the 50,000

187 Monte Carlo simulations used for calibration. Figure 4 shows the dotty plots of all six 188 parameters for two contrasting catchments; rain dominated (in western Oregon) and snow 189 dominated (in Wyoming). It can be noted from this figure that the dot density is much higher for 190 the Oregon catchment, which suggests that it has a larger number of parameter combinations that 191 yield high NS values. In both catchments, $f$ is the most sensitive parameter with a narrow range 192 of values that produce high NS. While $S_{\max }$ is less sensitive to NS than $f$, certain value ranges of 193 the $S_{\max }$ parameter appear to be unfavorable for obtaining high NS. For the snow-dominated 194 catchment in Wyoming, we find that, in addition to $f$ and $S_{\max }$, parameter $D_{f}$ from the snow 195 model shows sensitivity to NS (Figure 4b). All three parameters from the snow component are 196 insensitive to NS at the rain-dominated catchment in Oregon (Figure 4a). This is expected since 197 the snow component of the EXP-HYDRO model will mostly be inactive in this catchment. 198 However, from the three parameters of the catchment bucket, we find that only $Q_{\max }$ remains 199 insensitive over its entire range in both catchments.

\subsection{Parameter estimation at ungauged catchments}

We use both physical similarity and spatial proximity based approaches to identify the

202 donor gauged catchments for parameter transfer. In the physical similarity approach, physio- 
203 climatic attributes of each catchment are obtained, and the catchment that is most similar to the

204

205

206

207

208

209

210

211

212

213

214

215

216

217

218

219

220 221 scheme 3, the sensitive parameters are chosen randomly within their parameter range and the 222 insensitive parameters are transferred from gauged catchment. In scheme 4, all six parameters

223 are chosen randomly within their parameter range and no information is transferred from the 224 donor gauged catchment to an ungauged catchment.

where, $J$ is the total number of catchment attributes $\left(J=7\right.$ in our case), $X_{a, j}$ is the value of an attribute at catchment $a$, and $\max \left(X_{j}\right)-\min \left(X_{j}\right)$ is the range of that attribute among all the catchments considered. Gauged catchment with the lowest value of dist is chosen as the donor catchment. In the spatial proximity approach, only geographic distance among catchments is considered. We use the Euclidean distance between the stream gauge locations to quantify spatial proximity. Gauged catchment that is located closest to the ungauged catchment is chosen as the donor catchment.

Using the above two approaches, we test four different schemes of parameter estimation at an ungauged catchment. In scheme 1, all six parameters of the EXP-HYDRO model are transferred from the donor gauged catchment. In scheme 2, only the sensitive parameters $(f$, $S_{\max }$, and $\left.D_{f}\right)$ are transferred from the gauged catchment and the insensitive parameters $\left(Q_{\max }\right.$, $T_{\min }$, and $\left.T_{\max }\right)$ are assigned a random value within their parameter range (see Table 2 ). In 
$226 \quad 4 . \quad$ Results

$227 \quad 4.1 \quad$ Model performance at gauged catchments

228 Based on the calibration performance of EXP-HYDRO model, we first identify the 229 gauged catchments that meet our criterion for acceptable performance (NS > 0.6). If a catchment 230 can be calibrated with NS > 0.6, we consider the structure of EXP-HYDRO model to be suitable 231 for the simulation of hydrologic dynamics at that catchment. While this criterion is subjective in 232 nature, our observations of simulated hydrographs at numerous catchments suggested that, even 233 if each event is not simulated accurately, hydrographs with NS > 0.6 can reliably mimic the 234 overall observed hydrologic patterns across several years. Figure 5 shows the geographic 235 distribution of catchments that are "accepted" and "rejected" based on our criterion. Out of the 236756 catchments, 323 catchments $(\sim 43 \%)$ have calibrated model performance with NS > 0.6. 237 Majority of the accepted catchments are located in three distinct geographic regions: (1) in the 238 eastern half of the US, mainly along Appalachian Mountain Range, but also in some mid-western 239 and southern states on either side of the Mississippi river; (2) along the Rocky Mountain Range 240 in the states of Idaho, Wyoming, and Colorado; and (3) along the Pacific coast, to the west of the

241 Cascade and the Sierra Nevada Mountain Ranges. On the other hand, majority of the rejected 242 catchments (NS < 0.6) are located in the drier central part of the US, the rain-shadow regions in 243 western US, along the Gulf Coast, and to the east of the Appalachian Mountain Range in Mid244 Atlantic States.

\section{$245 \quad 4.2 \quad$ Model performance at ungauged catchments}

246 For the transfer of model parameters to the ungauged catchments, we only consider the 247323 accepted catchments where we know a priori that the EXP-HYDRO model structure is 
248 suitable. Each of the 323 catchments is considered ungauged in turn, its donor gauged catchment

249 is chosen (based on either spatial proximity or physical similarity), and appropriate model

250 information is transferred to this pseudo-ungauged catchment based on the four parameter

251 estimation schemes described in Section 3.3.

252 We first compare the spatial proximity and physical similarity approaches in terms of

253 model performance at ungauged catchments. For direct comparison of these two approaches, we

254 only consider model predictions from scheme 1, where all six parameters are transferred from

255 gauged to ungauged catchments. Figure 6a shows the empirical CDF (cumulative distribution

256 function) plot of the NS values for calibration case (blue line), spatial proximity based parameter

257 transfer (red line), and physical similarity based parameter transfer (black line). Both spatial

258 proximity and physical similarity approaches provide similar overall model performance, but NS

259 values are slightly higher for the spatial proximity approach at high percentiles. Figure 6b

260 provides a 1:1 comparison of the NS values from these two parameter transfer approaches. In

261202 catchments (out of 323 in total; 63\%), NS values are equal or higher with the spatial

262 proximity approach than with the physical similarity approach. Figure 7 shows the map of

263 catchments where either of these two approaches performs better. We find no distinct

264 geographic regions where one approach has a complete advantage over the other. In terms of

265 acceptable model performance, 187 catchments $(\sim 58 \%)$ have NS $>0.6$ using the spatial

266 proximity approach, whereas 179 catchments $(\sim 55 \%)$ have NS $>0.6$ using the physical

267 similarity approach.

268 Next, we compare the model performance at ungauged catchments using the four 269 parameter estimation schemes (see Section 3.3). Our goal in testing these schemes is to 270 determine if transfer of sensitive parameters from gauged catchments is more valuable for 
271 streamflow prediction at ungauged catchments than the transfer of insensitive parameters.

272 Figure 8 compares these four schemes through the empirical CDF plots and box plots of NS

273 values. For both spatial proximity and physical similarity approaches, we find that although

274 scheme 1 (all six parameters transferred) provides the best overall predictability for the pseudo-

275 ungauged scenario, scheme 2 (sensitive parameters transferred; insensitive parameters chosen

276 randomly within parameter range) provides predictability that is almost on par with scheme 1 ,

277 especially at higher percentiles of NS. Scheme 3 (insensitive parameters transferred; sensitive

278 parameters chosen randomly within parameter range) and scheme 4 (all six parameters chosen

279 randomly within parameter range) provide a model performance that is significantly deteriorated

280 compared to the performance from schemes 1 and 2 . It is worth noting here that when only

281 insensitive parameters are transferred, the model performance is almost equivalent to that of

282 using a completely randomized parameter set. Box plot comparison (Figure 8) of these four

283 schemes shows that the variability of NS among the 323 catchments is substantially smaller (and 284 almost similar) for schemes 1 and 2, compared to that for schemes 3 and 4.

286 5. Discussion

In terms of parameter transfer from gauged to ungauged catchments, regionalization 288 studies in the past have not treated sensitive and insensitive model parameters differently. Some 289 have even recommended transfer of the entire calibrated parameter set to ensure that internal 290 dependencies or correlations among optimized model parameters are preserved [McIntyre et al., 291 2005; Oudin et al., 2008]. Kokkonen et al. [2003] stated that “...when there is a reason to 292 believe that, in the sense of hydrological behaviour, a gauged catchment resembles the ungauged 293 catchment to a sufficient extent, it may be worthwhile to adopt the entire set of calibrated 
294 parameters from the gauged catchment". While our results are in general agreement with this 295 recommendation, they certainly reveal that major differences exist when different type of model 296 information is transferred selectively. Specifically, we find that the success of streamflow 297 prediction at an ungauged catchment depends largely on the transfer of model parameters that are 298 sensitive to our objective function (NS). On the other hand, transfer of insensitive model 299 parameters from the donor gauged catchments is significantly less valuable if sensitive 300 parameters are not well estimated in the first place. The importance of sensitive parameters at 301 gauged catchments is obvious, since deviations from the optimal values will likely result in 302 significant performance decline (see Figure 3). It is less intuitive, however, that these same 303 (sensitive) parameters would retain their importance when transferring information from gauged 304 to ungauged catchments. This suggests that the sensitive model parameters not only contain 305 information that controls the hydrologic behavior at gauged catchments, but they also determine 306 the extent to which streamflow predictability can be achieved at an ungauged catchment in the 307 region.

Although identifying the exact hydrologic information contained in calibrated model 309 parameters can be difficult in some cases, the individual role played by each parameter within 310 the model structure offers clues into the hydrologic processes that they represent. All the three 311 sensitive parameters of EXP-HYDRO model convey different aspects of the hydrograph 312 recession information. Parameters $f$ and $D_{f}$ essentially control the rate of depletion of water and 313 snow storage reservoirs within the catchment. $S_{\max }$, on the other hand, represents an effective 314 depth within the catchment at which flow contribution to the stream ceases. Small value of $S_{\max }$ 315 indicates a shallow system that is most likely dominated by flow paths with short residence 316 times, whereas large value of $S_{\max }$ suggests a deep system that allows for greater contribution 
317 from slower flow paths. This phenomenon is noticeable in Figure 9 which shows that an inverse 318 relationship exists between $f$ and $S_{\max }$ for the 323 accepted catchments. Specifically, the rate of 319 depletion $f$ tends to be slower for a deep bucket (high $S_{\max }$ ), which prolongs the hydrograph 320 recession due to greater contributions from slower (and perhaps deeper) flow paths. A shallow 321 bucket (low $S_{\max }$ ) tends to show the opposite behavior where a quicker depletion of the 322 hydrograph recession limb occurs. The presence of insensitive parameters in a model might 323 reflect an inadequate understanding or representation of some hydrologic processes within the 324 model structure. For instance, $Q_{\max }$ represents the maximum flow contribution from the 325 catchment bucket when it is completely saturated. Ideally, this parameter can be well 326 constrained since it is conceptually related to the lateral conductivity of a saturated soil column. 327 However, due to our incomplete knowledge of the internal heterogeneity and macropore 328 structure of soils within the catchment, this parameter might have become insensitive in practice. 329 Parameters $T_{\max }$ and $T_{\min }$ also show insensitivity to the objective function. A likely reason for 330 this could be the simplistic representation of snow processes in the thermal degree-day snow 331 model, which is solely dependent on the surface air temperature. A more complex representation 332 of the snow accumulation and melt processes might help in reducing the insensitivity of such 333 snow-related parameters.

334 Comparison of the spatial proximity and physical similarity approaches showed that 335 almost similar model performance is achieved with either approach. This is consistent with 336 previous studies that have compared these two approaches, but by using different combinations 337 of physio-climatic attributes for the physical similarity approach [Parajka et al., 2005; Oudin et 338 al., 2008; Zhang and Chiew, 2009]. For instance, Oudin et al. [2008] used six attributes, viz., 339 catchment area, catchment slope, median altitude, drainage density, fraction of forest cover, and 
340 aridity index. Zhang and Chiew [2009] used eight attributes, such as area, aridity index, mean 341 elevation, mean slope, stream length, mean solum thickness, plant available water holding 342 capacity, and mean woody vegetation fraction. These differences are reflective of the disparity 343 that exists in available geophysical data from various parts of the world. Regardless of the 344 combination used, however, a physical similarity based framework typically contains both 345 physiographic and climatic attributes. To gain further insight into the relative influence of each, 346 we compare the model performance when only physiographic vs. climatic attributes are used to 347 identify donor catchments. Figure 10a shows the CDF plot of NS values for the 323 pseudo348 ungauged catchments with three scenarios for selecting a donor gauged catchment: (1) all seven 349 attributes are used, (2) only climatic attributes (aridity index, solar radiation, percentage 350 precipitation as snow) are used, and (3) only physiographic attributes (drainage area, channel 351 slope, mean elevation, soil permeability) are used. We find that the model performance with 352 considering climatic attributes only is marginally better than that with considering physiographic 353 attributes only. This suggests that, on their own, the climatic attributes have slightly more 354 explanatory power regarding catchment similarity than our chosen physiographic attributes. One 355 reason could be that a stronger connection exists between climatic similarity and spatial 356 proximity, i.e., catchments having similar climate are more likely to be located close to each 357 other. Figure $10 \mathrm{~b}$ shows a 1:1 comparison of the NS values obtained with climatic and 358 physiographic attributes. While most catchments have NS values close to the 1:1 line, large 359 scatter in this relationship suggests that climatic similarity is clearly preferred to physiographic 360 similarity (and vice versa) in some catchments. Nonetheless, the best performance is still 361 achieved when both physiographic and climatic attributes are used within a catchment similarity 362 framework. 
The EXP-HYDRO model developed in this study performs satisfactorily (NS > 0.6) in

only $43 \%$ of the 756 catchments. Nonetheless, the geographic distribution of good predictability catchments (Figure 5) is similar to that observed by previous modeling studies within the

366 continental US, even though completely different models and temporal resolution (monthly)

367 were used in these studies [Hay and McCabe, 2002; Martinez and Gupta, 2010]. We think that 368 any other model which is implementable across a large number of catchments will likely produce 369 similar geographic patterns of streamflow predictability. The method that we used to identify 370 important vs. non-important information within the EXP-HYDRO model is based on our 371 observation of parameter sensitivity to a single objective function (NS). It is likely that the 372 sensitivity of a model parameter will be different if other objective functions are used, in which 373 case a completely different set of parameters will become important. Regardless of the objective 374 function used, however, a modeler will have to analyze the role played by a particular parameter 375 in representing the function of the system, and then take a decision as to whether that parameter 376 conveys meaningful information or not. Overall, we think that the findings from this study are 377 generic enough in nature and applicable to any modeling framework. While parameters with 378 different sensitivities will almost always exist in any model structure, identifying the key 379 information that controls model behavior will certainly lead to progress in our understanding of 380 the hydrologic systems.

\section{6. Concluding remarks}

In this study, we tested the hypothesis that there is some core information, contained within a subset of all calibrated model parameters, whose transfer from gauged to ungauged 385 catchments is the most critical factor for successful streamflow predictions. To this end, we 
386 developed a simple daily time-step rainfall-runoff model (EXP-HYDRO) and implemented it

387 over 756 catchments across the continental United States. Both spatial proximity and physical

388 similarity based approaches were tested to identify the donor gauged catchments for parameter

389 transfer. Based on the results, we conclude that streamflow predictability at ungauged

390 catchments using rainfall-runoff models is largely dependent on the transfer of a small subset of

391 parameters from donor gauged catchments. In the case of EXP-HYDRO model, this subset

392 consists of three parameters that convey different aspects of the hydrograph recession

393 information, and are also sensitive to our objective function (NS). Importantly, we find that the

394 transfer of this key information is essential regardless of the approach used for identifying the

395 donor gauged catchments. We further recommend that, in any modeling framework, the core

396 subset of important parameters should be identified and better characterized in order to

397 understand the information that controls predictability at ungauged catchments.

\section{Acknowledgements}

399 This research was supported by the following NSF grants: ARC-0922100 and EAR-1027870.

400 The authors would like to thank Dr. Malcolm Anderson (editor) for facilitating a thorough

401 review, and the anonymous reviewers for providing insightful comments that have greatly 402 improved this manuscript.

403

404 Appendix A: Thermal degree-day snow model

The EXP-HYDRO model contains two buckets, a catchment bucket and a snow

406 accumulation bucket. Only the precipitation that is considered as snowfall accumulates in the

407 snow bucket, whereas the rainfall accumulates directly in the catchment bucket. The daily

408 precipitation $P$ is classified as snowfall or rainfall based on the following conditions: 
If $T_{a}<T_{\min }$,

410

$$
\begin{aligned}
& P_{s}=P \\
& P_{r}=0
\end{aligned}
$$

411 Else,

412

$$
\begin{aligned}
& P_{s}=0 \\
& P_{r}=P
\end{aligned}
$$

413 where, $P_{s}$ is snowfall in $\mathrm{mm} /$ day, $P_{r}$ is rainfall in $\mathrm{mm} /$ day, and $T_{a}$ is daily air temperature in ${ }^{\circ} \mathrm{C}$.

414 Water balance of the snow bucket is as follows:

415

$$
\frac{d S_{\text {snow }}}{d t}=P_{s}-M
$$

416 Where, $S_{\text {snow }}$ is the storage in snow bucket (unit: $\mathrm{mm}$ ), and $M$ is the snowmelt (unit: $\mathrm{mm} / \mathrm{day}$ ).

417 The amount of snowmelt $M$ is modeled using the thermal degree-day concept as follows:

418 If $S_{\text {snow }}>0$ and $T_{a}>T_{\max }$,

419

$$
M=\min \left\{S_{\text {snow }}, D_{f} \cdot\left(T_{a}-T_{\max }\right)\right\}
$$

420 Else,

421

$$
M=0
$$

422 where, $D_{f}$ is the thermal degree-day factor (unit: $\mathrm{mm} / \mathrm{day} /{ }^{\circ} \mathrm{C}$ ), and $T_{\max }$ is the temperature

423 threshold above which accumulated snow begins to melt. The snowmelt $M$ from the snow 424 bucket is input to the catchment bucket (see Equation 1).

425

426

427

428

429

\section{References}

Abdelnour, A., M. Stieglitz, F. Pan, and R. McKane (2011), Catchment hydrological responses to forest harvest amount and spatial pattern, Water Resources Research, 47(9), W09521, doi: 10.1029/2010wr010165. 
Archfield, S. A., and R. M. Vogel (2010), Map correlation method: Selection of a reference streamgage to estimate daily streamflow at ungaged catchments, Water Resources Research, 46(10), W10513, doi: 10.1029/2009wr008481.

Beven, K. J. (1989), Changing ideas in hydrology - The case of physically-based models, Journal of Hydrology, 105(1-2), 157-172, doi: 10.1016/0022-1694(89)90101-7.

Beven, K. J. (2001), Rainfall-Runoff Modelling: The Primer, 319 pp., John Wiley \& Sons, Ltd., Chichester.

Beven, K. J., and M. J. Kirkby (1979), A physically based, variable contributing area model of basin hydrology / Un modèle à base physique de zone d'appel variable de l'hydrologie du bassin versant, Hydrological Sciences Bulletin, 24(1), 43-69, doi: $10.1080 / 02626667909491834$.

Beven, K. J., and A. Binley (1992), The future of distributed models: Model calibration and uncertainty prediction, Hydrological Processes, 6(3), 279-298, doi: 10.1002/hyp.3360060305.

Blöschl, G. (2006), Rainfall-Runoff Modeling of Ungauged Catchments, in Encyclopedia of Hydrological Sciences, edited, John Wiley \& Sons, Ltd, doi: 10.1002/0470848944.hsa140.

Burn, D. H., and D. B. Boorman (1993), Estimation of hydrological parameters at ungauged catchments, Journal of Hydrology, 143(3-4), 429-454, doi: 10.1016/00221694(93)90203-1.

Christensen, N. S., A. W. Wood, N. Voisin, D. P. Lettenmaier, and R. N. Palmer (2004), The Effects of Climate Change on the Hydrology and Water Resources of the Colorado River Basin, Climatic Change, 62(1), 337-363, doi: 10.1023/B:CLIM.0000013684.13621.1f.

Dingman, S. L. (2002), Physical hydrology, 600 pp., Prentice Hall, New Jersey.

Doherty, J., and R. J. Hunt (2009), Two statistics for evaluating parameter identifiability and error reduction, Journal of Hydrology, 366(1-4), 119-127, doi: 10.1016/j.jhydrol.2008.12.018.

Hamlet, A. F., and D. P. Lettenmaier (1999), Effects of Climate Change on Hydrology and Water Resources in the Columbia River Basin, Journal of the American Water Resources Association, 35(6), 1597-1623, doi: 10.1111/j.1752-1688.1999.tb04240.x.

Hamon, W. R. (1963), Computation of direct runoff amounts from storm rainfall, Int. Assoc. Sci. Hydrol. Publ, 63, 52-62, doi.

Hay, L. E., and G. J. McCabe (2002), Spatial variability in water-balance model performance in the conterminous United States, Journal of the American Water Resources Association, 38(3), 847-860, doi: 10.1111/j.1752-1688.2002.tb01001.x. 
Kokkonen, T. S., A. J. Jakeman, P. C. Young, and H. J. Koivusalo (2003), Predicting daily flows in ungauged catchments: model regionalization from catchment descriptors at the Coweeta Hydrologic Laboratory, North Carolina, Hydrological Processes, 17(11), 22192238, doi: 10.1002/hyp.1329.

Krysanova, V., D.-I. Müller-Wohlfeil, and A. Becker (1998), Development and test of a spatially distributed hydrological/water quality model for mesoscale watersheds, Ecological Modelling, 106(2-3), 261-289, doi: 10.1016/s0304-3800(97)00204-4.

Martinez, G. F., and H. V. Gupta (2010), Toward improved identification of hydrological models: A diagnostic evaluation of the "abcd" monthly water balance model for the conterminous United States, Water Resources Research, 46(8), W08507, doi: 10.1029/2009wr008294.

Maurer, E. P., A. W. Wood, J. C. Adam, D. P. Lettenmaier, and B. Nijssen (2002), A Long-Term Hydrologically Based Dataset of Land Surface Fluxes and States for the Conterminous United States, Journal of Climate, 15(22), 3237-3251, doi: 10.1175/15200442(2002)015<3237:althbd>2.0.co;2.

McIntyre, N., H. Lee, H. Wheater, A. Young, and T. Wagener (2005), Ensemble predictions of runoff in ungauged catchments, Water Resources Research, 41(12), W12434, doi: $10.1029 / 2005 \mathrm{wr} 004289$.

Merz, R., and G. Blöschl (2004), Regionalisation of catchment model parameters, Journal of Hydrology, 287(1-4), 95-123, doi: 10.1016/j.jhydrol.2003.09.028.

Merz, R., and G. Blöschl (2005), Flood frequency regionalisation-spatial proximity vs. catchment attributes, Journal of Hydrology, 302(1-4), 283-306, doi: 10.1016/j.jhydrol.2004.07.018.

Moretti, G., and A. Montanari (2008), Inferring the flood frequency distribution for an ungauged basin using a spatially distributed rainfall-runoff model, Hydrology and Earth System Sciences, 12(4), 1141-1152, doi: 10.5194/hess-12-1141-2008.

Mosley, M. P. (1981), Delimitation of New Zealand hydrologic regions, Journal of Hydrology, 49(1-2), 173-192, doi: 10.1016/0022-1694(81)90211-0.

Nash, J. E., and J. V. Sutcliffe (1970), River flow forecasting through conceptual models part I - A discussion of principles, Journal of Hydrology, 10(3), 282-290, doi: 10.1016/00221694(70)90255-6.

Notter, B., H. Hurni, U. Wiesmann, and K. C. Abbaspour (2012), Modelling water provision as an ecosystem service in a large East African river basin, Hydrology and Earth System Sciences, 16(1), 69-86, doi: 10.5194/hess-16-69-2012.

Oudin, L., A. Kay, V. Andréassian, and C. Perrin (2010), Are seemingly physically similar catchments truly hydrologically similar?, Water Resources Research, 46(11), W11558, doi: 10.1029/2009wr008887. 
Oudin, L., V. Andréassian, T. Mathevet, C. Perrin, and C. Michel (2006), Dynamic averaging of rainfall-runoff model simulations from complementary model parameterizations, Water Resources Research, 42(7), W07410, doi: 10.1029/2005wr004636.

Oudin, L., V. Andréassian, C. Perrin, C. Michel, and N. Le Moine (2008), Spatial proximity, physical similarity, regression and ungaged catchments: A comparison of regionalization approaches based on 913 French catchments, Water Resources Research, 44(3), W03413, doi: $10.1029 / 2007 \mathrm{wr} 006240$.

Parajka, J., R. Merz, and G. Blöschl (2005), A comparison of regionalisation methods for catchment model parameters, Hydrology and Earth System Sciences, 9(3), 157-171, doi: 10.5194/hess-9-157-2005.

Patil, S., and M. Stieglitz (2012), Controls on hydrologic similarity: role of nearby gauged catchments for prediction at an ungauged catchment, Hydrology and Earth System Sciences, 16(2), 551-562, doi: 10.5194/hess-16-551-2012.

Poff, N. L., B. D. Richter, A. H. Arthington, S. E. Bunn, R. J. Naiman, E. Kendy, M. Acreman, C. Apse, B. P. Bledsoe, M. C. Freeman, J. Henriksen, R. B. Jacobson, J. G. Kennen, D. M. Merritt, J. H. O'Keeffe, J. D. Olden, K. Rogers, R. E. Tharme, and A. Warner (2010), The ecological limits of hydrologic alteration (ELOHA): a new framework for developing regional environmental flow standards, Freshwater Biology, 55(1), 147-170, doi: 10.1111/j.1365-2427.2009.02204.x.

Rees, H. G., M. G. R. Holmes, A. R. Young, and S. R. Kansakar (2004), Recession-based hydrological models for estimating low flows in ungauged catchments in the Himalayas, Hydrology and Earth System Sciences, 8(5), 891-902, doi: 10.5194/hess-8-891-2004.

Servais, P., G. Billen, A. Goncalves, and T. Garcia-Armisen (2007), Modelling microbiological water quality in the Seine river drainage network: past, present and future situations, Hydrology and Earth System Sciences, 11(5), 1581-1592, doi: 10.5194/hess-11-15812007.

Shukla, S., and D. P. Lettenmaier (2011), Seasonal hydrologic prediction in the United States: understanding the role of initial hydrologic conditions and seasonal climate forecast skill, Hydrology and Earth System Sciences, 15(11), 3529-3538, doi: 10.5194/hess-15-35292011.

Singh, V. P. (1995), Computer models of watershed hydrology, 1144 pp., Water Resources Publications, Highlands Ranch, CO.

Singh, V. P., and D. A. Woolhiser (2002), Mathematical Modeling of Watershed Hydrology, Journal of Hydrologic Engineering, 7(4), 270-292, doi: 10.1061/(ASCE)10840699(2002)7:4(270).

Singh, V. P., and D. K. Frevert (2006), Watershed Models, Taylor \& Francis, Boca Raton, FL. 
Sivapalan, M., K. Takeuchi, S. W. Franks, V. K. Gupta, H. Karambiri, V. Lakshmi, X. Liang, J. J. McDonnell, E. M. Mendiondo, P. E. O'Connell, T. Oki, J. W. Pomeroy, D. Schertzer, S. Uhlenbrook, and E. Zehe (2003), IAHS Decade on Predictions in Ungauged Basins (PUB), 2003-2012: Shaping an exciting future for the hydrological sciences, Hydrological Sciences Journal, 48(6), 857-880, doi: 10.1623/hysj.48.6.857.51421.

Slack, J. R., A. Lumb, and J. M. Landwehr (1993), Hydro-Climatic Data Network (HCDN) Streamflow Data Set, 1874-1988: USGS Water-Resources Investigations Report 93-4076, U.S. Geological Survey, Reston, VA.

Smakhtin, V. U. (2001), Low flow hydrology: a review, Journal of Hydrology, 240(3-4), 147186, doi: 10.1016/s0022-1694(00)00340-1.

Staudinger, M., K. Stahl, J. Seibert, M. P. Clark, and L. M. Tallaksen (2011), Comparison of hydrological model structures based on recession and low flow simulations, Hydrology and Earth System Sciences, 15(11), 3447-3459, doi: 10.5194/hess-15-3447-2011.

Vandewiele, G. L., and A. Elias (1995), Monthly water balance of ungauged catchments obtained by geographical regionalization, Journal of Hydrology, 170(1-4), 277-291, doi: 10.1016/0022-1694(95)02681-e.

Vandewiele, G. L., C.-Y. Xu, and W. Huybrechts (1991), Regionalisation of physically-based water balance models in Belgium. Application to ungauged catchments, Water Resources Management, 5(3), 199-208, doi: 10.1007/bf00421989.

Vogel, R. M., and A. Sankarasubramanian (2005), Monthly Climate Data for Selected USGS HCDN Sites, 1951-1990, edited, Oak Ridge National Laboratory Distributed Active Archive Center, Oak Ridge, Tennessee, U.S.A.

Wagener, T., and A. Montanari (2011), Convergence of approaches toward reducing uncertainty in predictions in ungauged basins, Water Resources Research, 47(6), W06301, doi: 10.1029/2010wr009469.

Xu, H., R. G. Taylor, and Y. Xu (2011), Quantifying uncertainty in the impacts of climate change on river discharge in sub-catchments of the Yangtze and Yellow River Basins, China, Hydrology and Earth System Sciences, 15(1), 333-344, doi: 10.5194/hess-15-3332011.

Zealand, C. M., D. H. Burn, and S. P. Simonovic (1999), Short term streamflow forecasting using artificial neural networks, Journal of Hydrology, 214(1-4), 32-48, doi: 10.1016/s0022-1694(98)00242-x.

Zhang, Y., and F. H. S. Chiew (2009), Relative merits of different methods for runoff predictions in ungauged catchments, Water Resources Research, 45(7), W07412, doi: $10.1029 / 2008$ wr007504. 


\section{Tables}

Table 1: Distribution of the physio-climatic properties among 756 catchments

\begin{tabular}{cccccccc}
\hline & $\begin{array}{c}\text { Area } \\
\left(\mathrm{km}^{2}\right)\end{array}$ & $\begin{array}{c}\text { Elevation* } \\
(\mathrm{m})\end{array}$ & $\begin{array}{c}\text { Channel Slope* } \\
(\text { degrees })\end{array}$ & $\begin{array}{c}\text { Solar Radiation* } \\
(\mathrm{mm} / \mathrm{yr})\end{array}$ & $\begin{array}{c}\text { PPS* } \\
(\%)\end{array}$ & $\begin{array}{c}\text { Permeability* } \\
(\mathrm{mm})\end{array}$ & $\begin{array}{c}\text { Aridity } \\
\text { Index }\end{array}$ \\
\hline Max & 5102.30 & 3646.40 & 13.57 & 4830.60 & 71.93 & 166.20 & 3.07 \\
$75^{\text {th }} \%$ ile & 1665.40 & 785.48 & 3.37 & 4467.80 & 12.53 & 41.54 & 0.99 \\
$50^{\text {th }} \%$ ile & 748.51 & 382.06 & 0.75 & 4246.20 & 6.02 & 25.25 & 0.78 \\
$25^{\text {th }} \%$ ile & 310.80 & 232.53 & 0.36 & 4073.40 & 1.21 & 15.68 & 0.65 \\
Min & 23.31 & 7.19 & 0.03 & 3700.20 & 0.00 & 4.68 & 0.24 \\
\hline
\end{tabular}

* Data obtained from Vogel and Sankarasubramanian [2005] dataset

Table 2: Parameter ranges for calibration of EXP-HYDRO model

\begin{tabular}{clccc}
\hline Parameter & \multicolumn{1}{c}{ Description } & Units & Lower Limit & Upper Limit \\
\hline$f$ & Rate of decline in runoff from catchment bucket & $\mathrm{mm}^{-1}$ & 0.0 & 0.1 \\
$S_{\max }$ & Maximum storage of the catchment bucket & $\mathrm{mm}$ & 100.0 & 1500.0 \\
$Q_{\max }$ & Maximum subsurface runoff at full bucket & $\mathrm{mm} / \mathrm{day}$ & 10.0 & 50.0 \\
$D_{f}$ & Thermal degree-day factor & $\mathrm{mm} / \mathrm{day} /{ }^{\circ} \mathrm{C}$ & 0.0 & 5.0 \\
$T_{\max }$ & Temperature above which snow starts melting & ${ }^{\circ} \mathrm{C}$ & 0.0 & 3.0 \\
$T_{\min }$ & Temperature below which precipitation is snow & ${ }^{\circ} \mathrm{C}$ & -3.0 & 0.0 \\
\hline
\end{tabular}


Figures

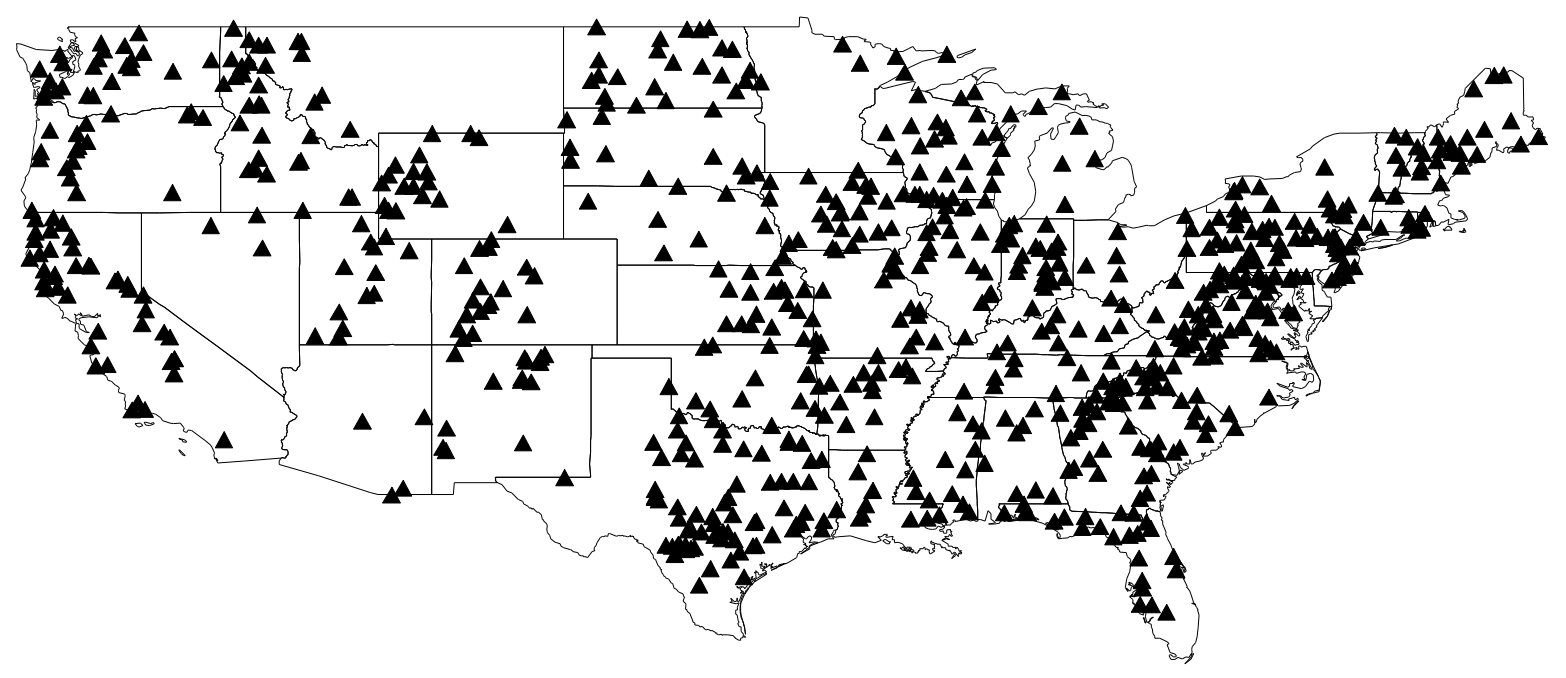

Figure 1: Location of the 756 study catchments within continental United States. 


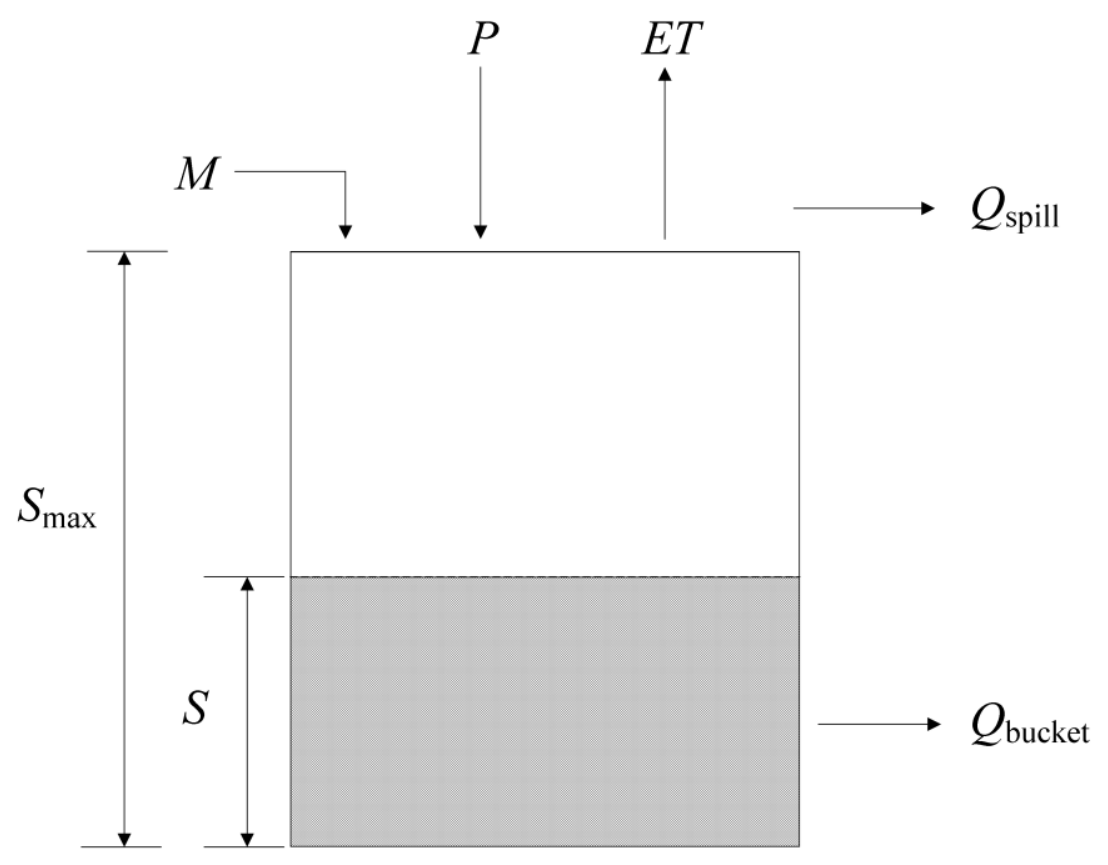

Figure 2: Schematic representation of the EXP-HYDRO rainfall-runoff model. 


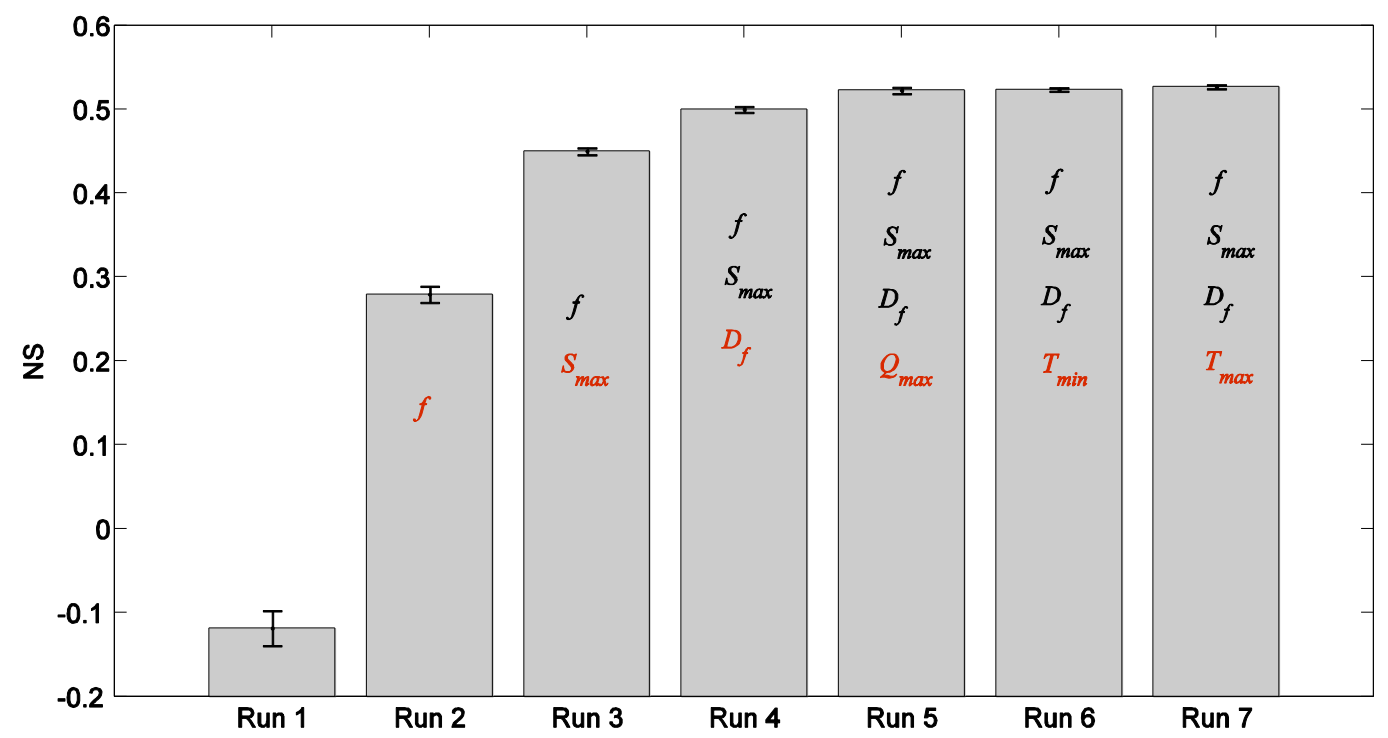

Figure 3: NS values obtained with multiple parameter estimation scenarios. Gray bar denotes median NS among the 756 catchments, and the error bars denote the 25th and 75 th percentile values of median NS (obtained through 1000 iterative model runs). For model runs 2 to 7 , parameter highlighted in red is the new parameter that is fixed to its calibrated value compared to previous model runs. 

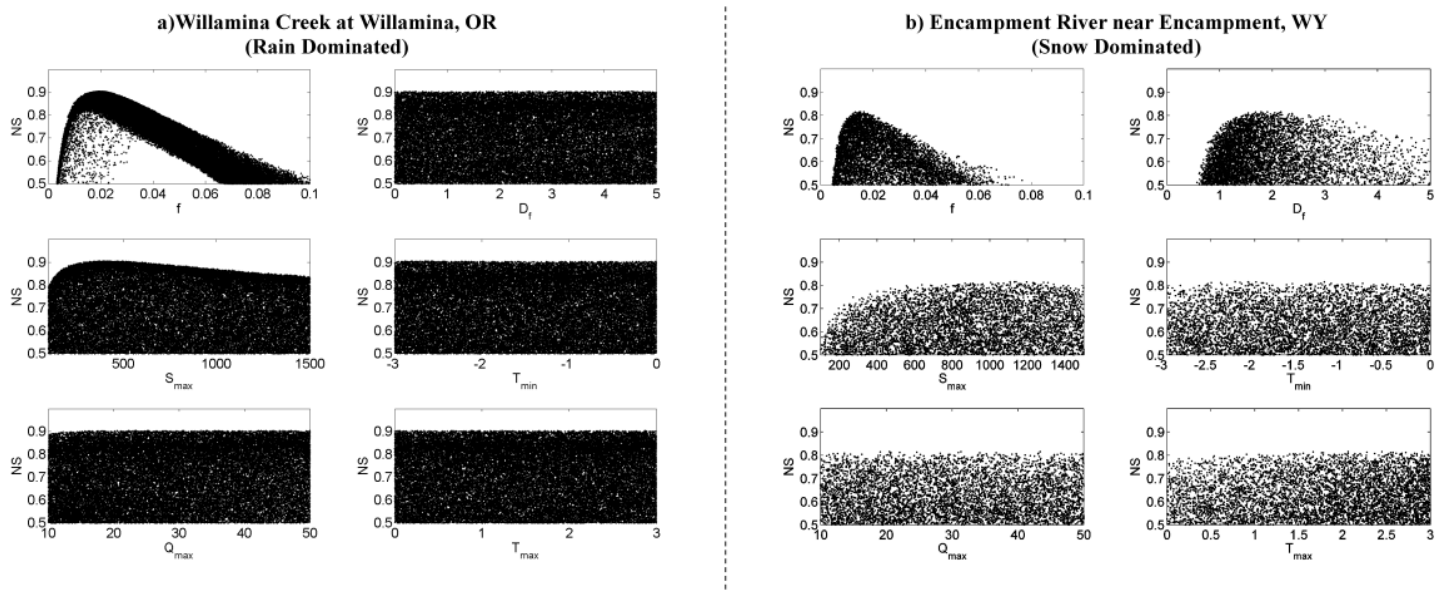

Figure 4: Dotty plots of the model parameters from 50,000 Monte Carlo simulations for a) Willamina Creek in Oregon (rain dominated), and b) Encampment River in Wyoming (snow dominated). 


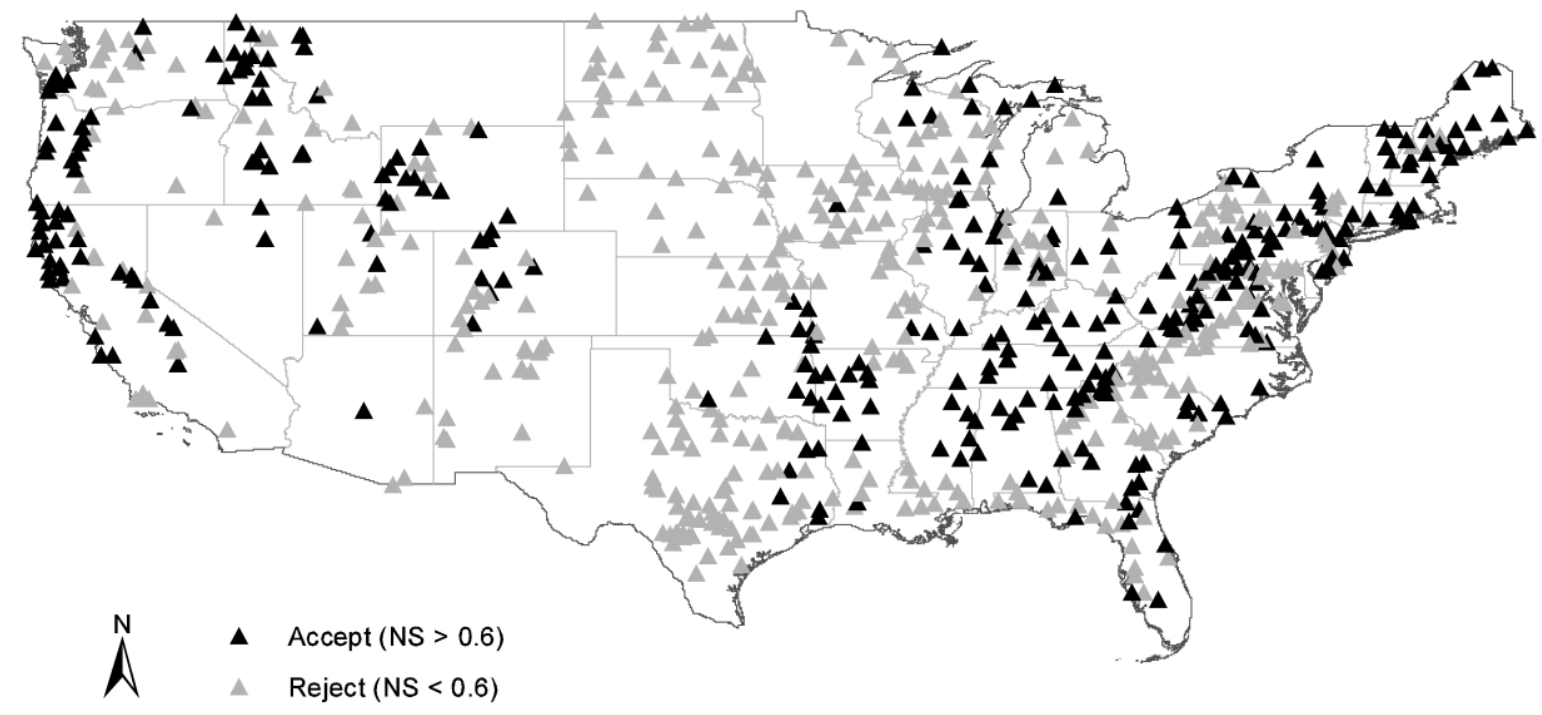

Figure 5: Location of the catchments that are either "accepted" or "rejected" based on the model performance criterion. 
a) CDF Plot (Spatial Proximity vs. Physical Similarity)

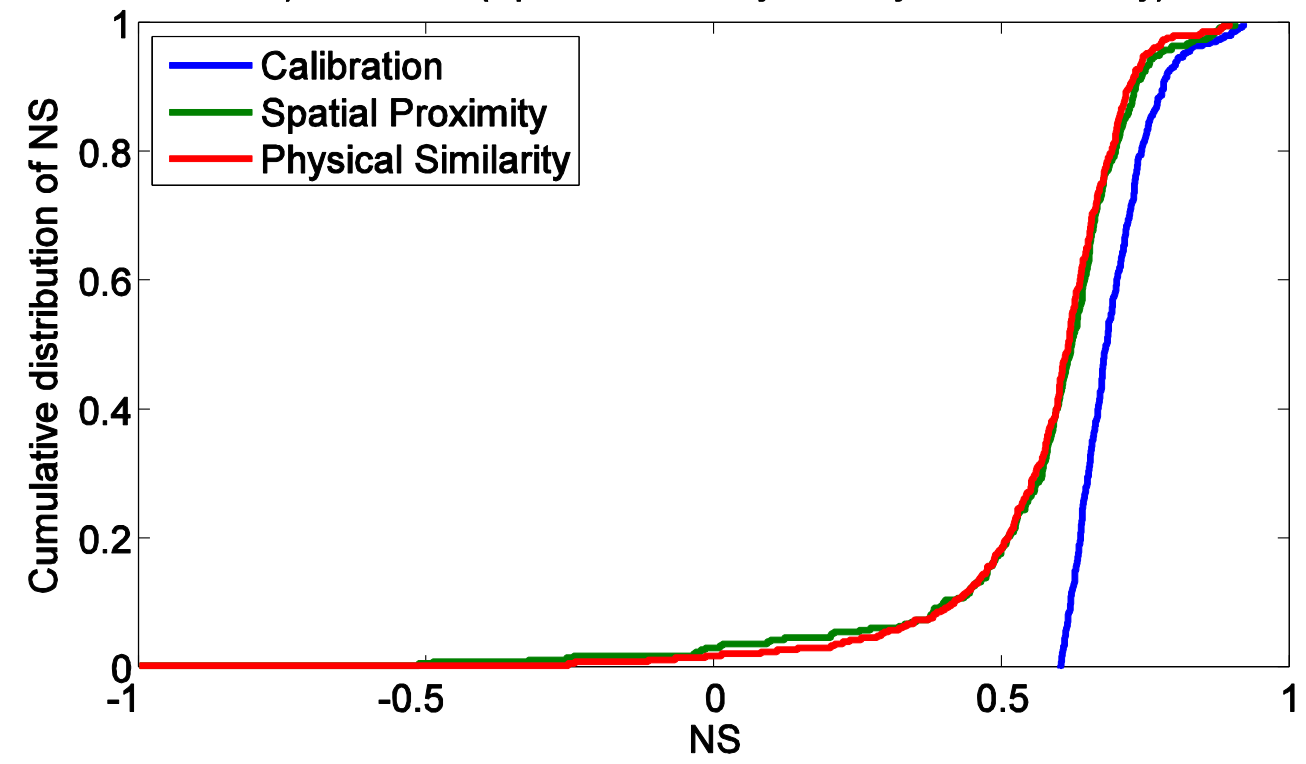

b) 1:1 Comparison (Spatial Proximity vs. Physical Similarity)

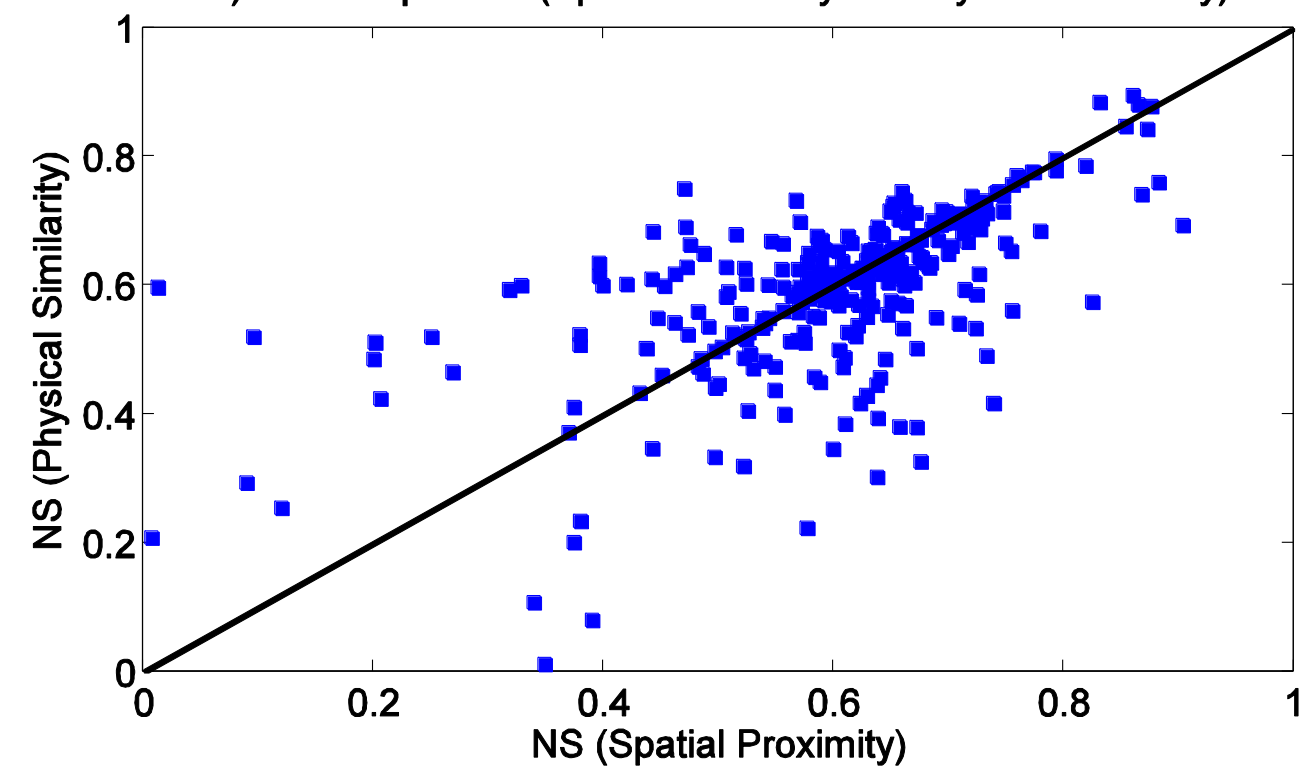

Figure 6: Comparison of the spatial proximity and physical similarity approaches with a) CDF plot, and b) 1:1 comparison of NS values. 


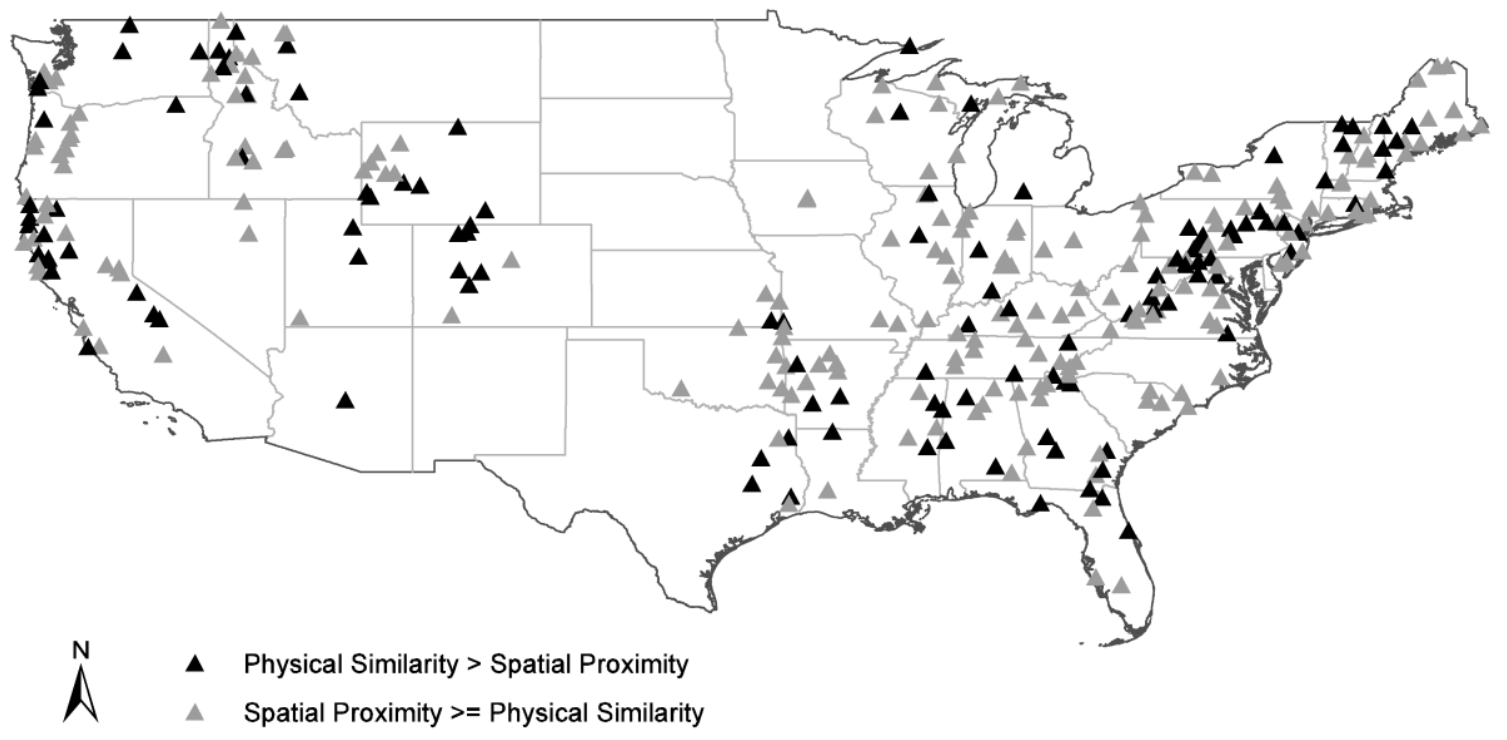

Figure 7: Location of the catchments where the model performance with spatial proximity approach is better (or equal) and worse than the physical similarity approach. 

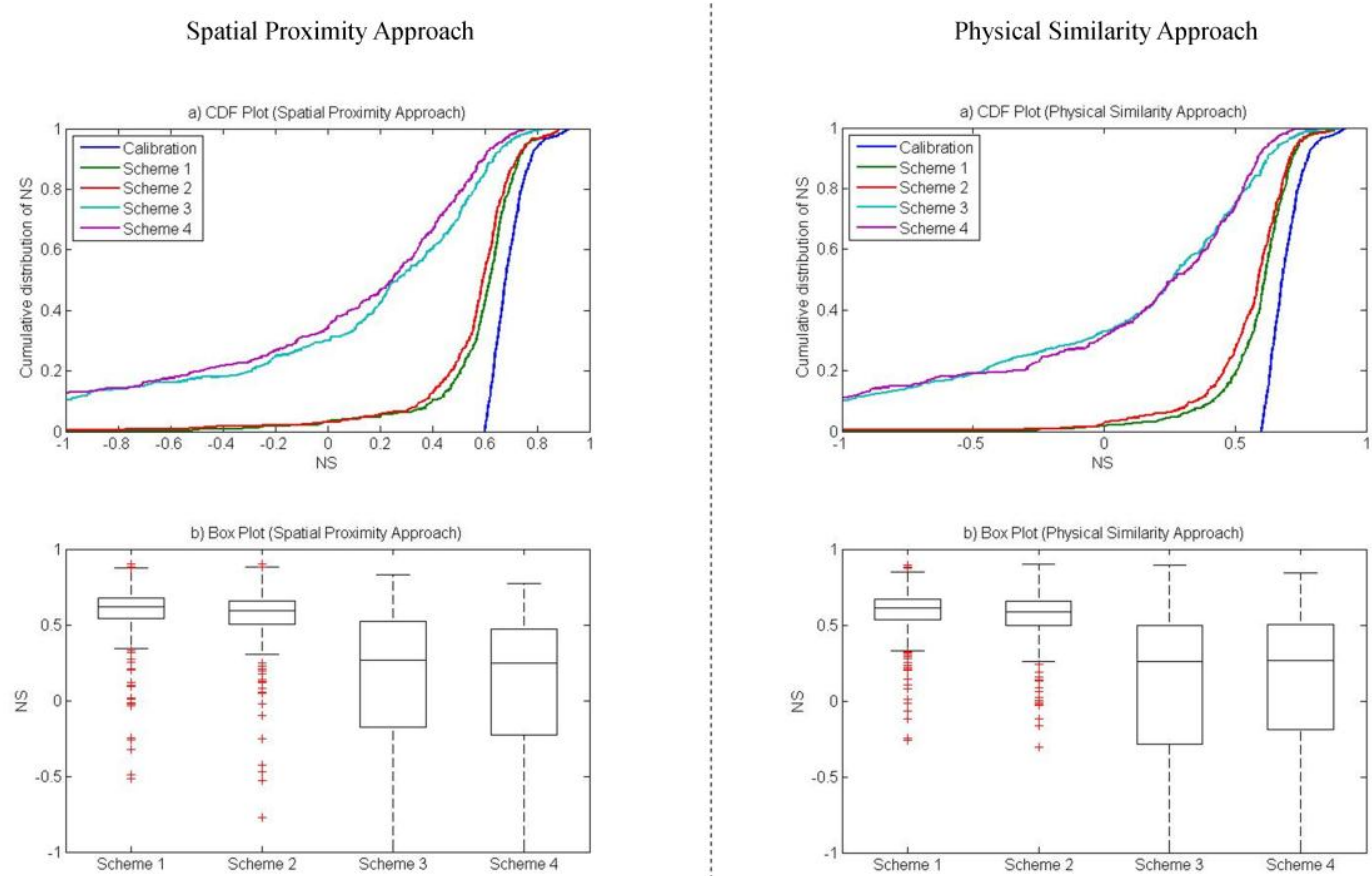

Figure 8: Comparison of model performance at ungauged catchments with the four parameter transfer schemes for spatial proximity and physical similarity approaches. 


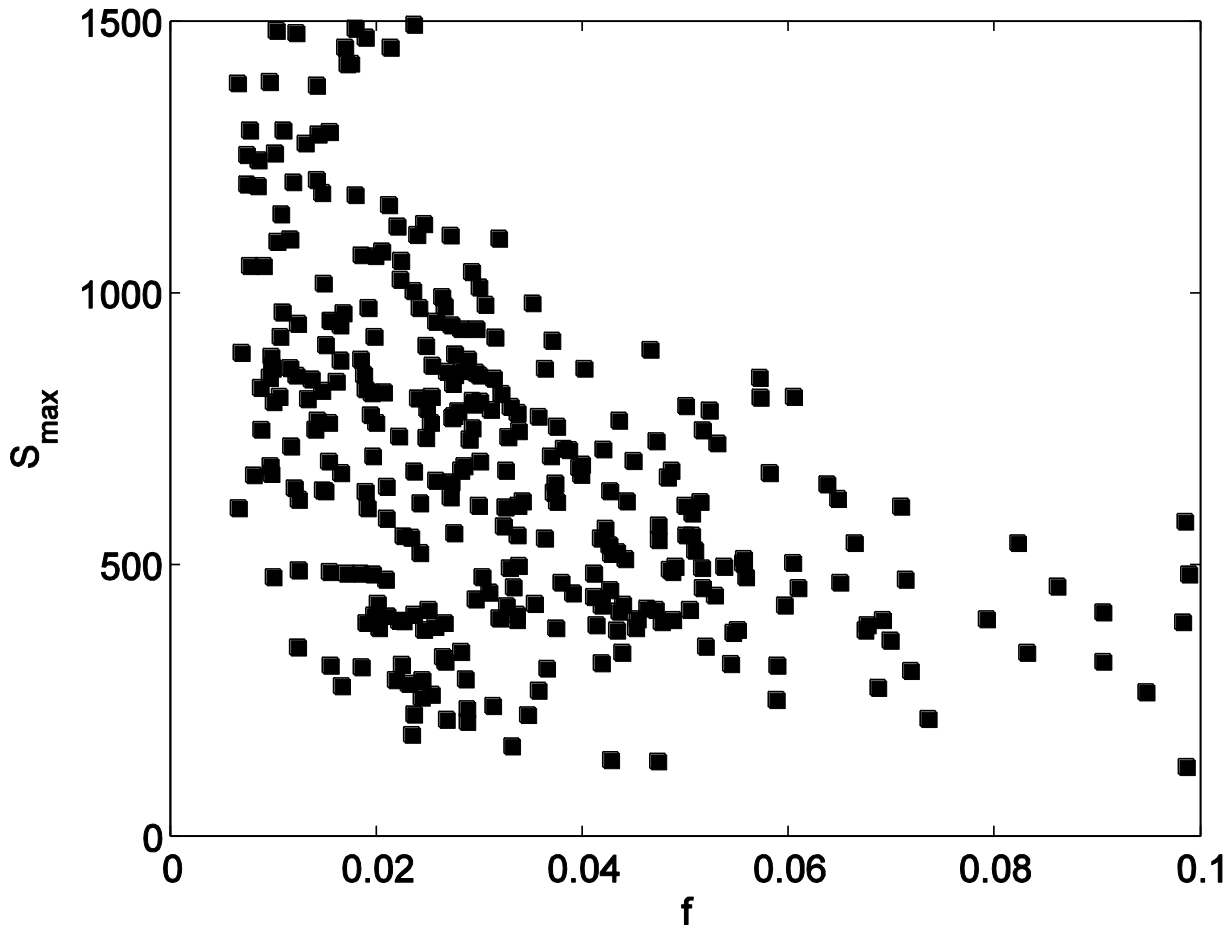

Figure 9: Relationship between calibration parameters $f$ and $S_{\max }$ with data from 323 accepted catchments. 


\section{a) CDF Plot}

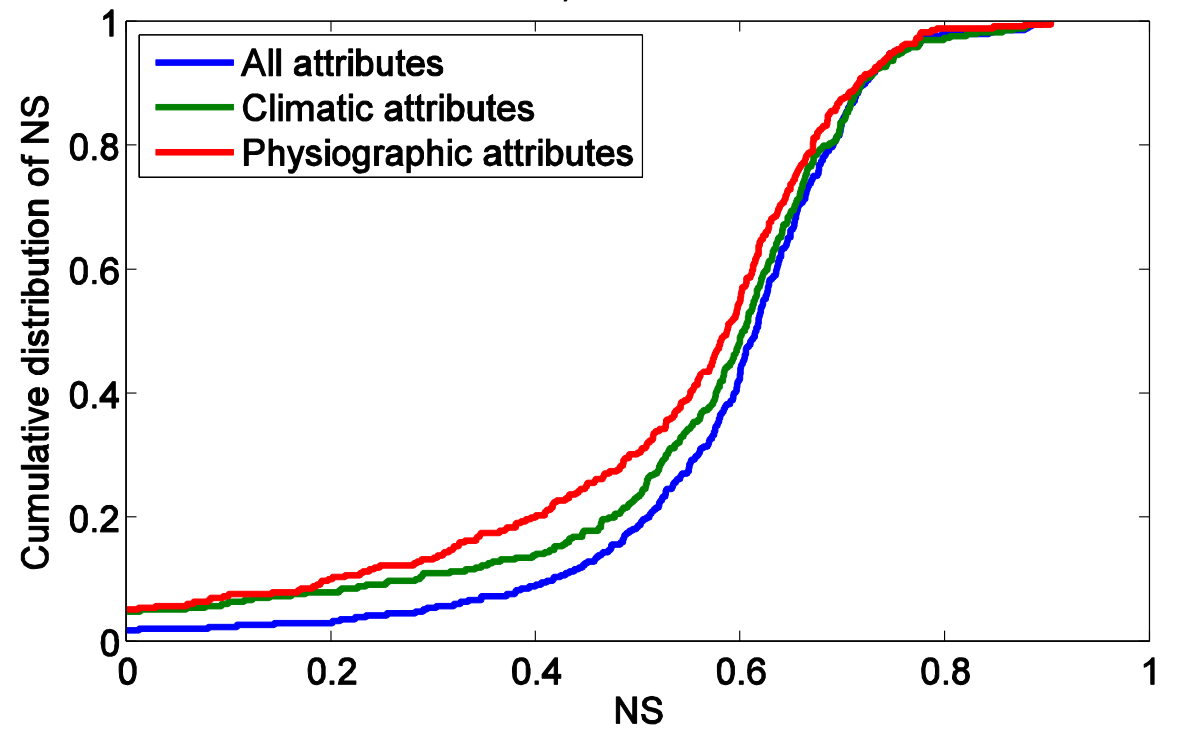

b) 1:1 Comparison (Climatic vs. Physiographic attributes)

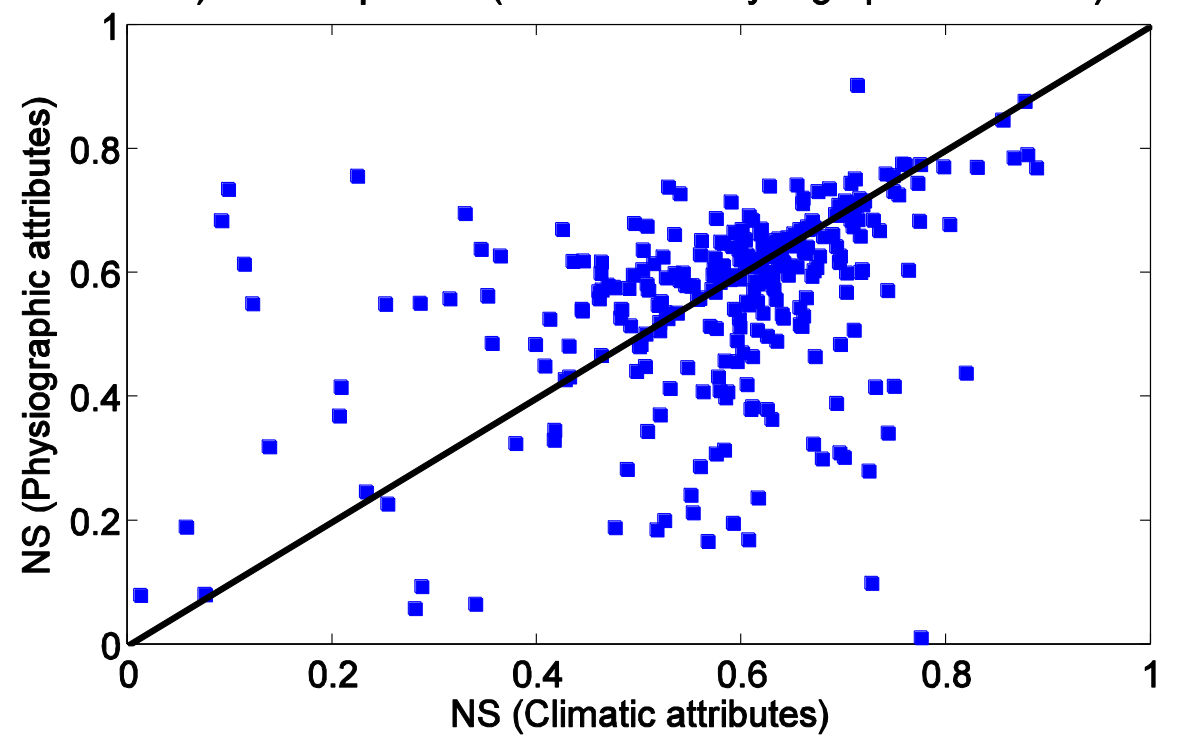

Figure 10: Comparison of climatic and physiographic attributes within the physical similarity based framework using a) CDF plot of NS values, and b) 1:1 comparison of NS values. 